\title{
Peran Moderasi Prio Opinion Terhadap Hubungan Prediksi Kebangkrutan Dengan Opini Audit Going Concern
}

\author{
Rudi Zulfikar ${ }^{1}$, Anggie Lestari ${ }^{2}$, Nana Nofianti ${ }^{3}$, dan Kurniasih Dwi Astuti ${ }^{4}$ \\ 1,2,3,4 Fakultas Ekonomi dan Bisnis, Universitas Sultan Ageng Tirtayasa, Serang \\ Email Adress: \\ "rz-zulfikar72@untirta.ac.id,anggi@yahoo.com,nofianti@untirta.ac.id,nien_rz@untirta.ac.id \\ *Coresponding Author
}

\begin{abstract}
This study examines the effect of ongoing bankruptcy predictions on audit opinions with previous opinions as moderating variables in the manufacturing industry listed on the Indonesia Stock Exchange during the 2014-2019 period. Measurement of bankruptcy prediction variables using Altman's.Z-Score. The sampling technique used in this research is the purposive.sampling method. In.addition, the regression analysis.model used to examine the interaction of bankruptcy prediction variables with previous opinions uses Moderated.Regression Analysis (MRA). The test results prove that the bankruptcy prediction as measured by Altman's Z-Score has a negative effect on ongoing concern audit opinion. Other evidence confirms that the prior opinion variable as measured by the dummy variable reduces the relationship between bankruptcy prediction and going concern audit opinion.
\end{abstract}

Keyword: Bankruptcy Prediction, Firm Size, Going Concern Audit Opinion, Prior Opinion, Year Dummy.

\begin{abstract}
Abstrak: Penelitian ini menguji pengaruh prediksi kebangkrutan berkelanjutan terhadap opini audit dengan opini sebelumnya sebagai variabel pemoderasi pada industri manufaktur yang terdaftar di Bursa Efek Indonesia periode 2014-2019. Pengukuran variabel prediksi kebangkrutan menggunakan Altman's.Z-Score. Teknik pengambilan sampel yang digunakan dalam penelitian ini adalah metode purposive.sampling. Selain itu, model analisis regresi yang digunakan untuk menguji interaksi variabel prediksi kebangkrutan dengan pendapat sebelumnya menggunakan Moderated.Regression Analysis (MRA). Hasil pengujian membuktikan bahwa prediksi kebangkrutan yang diukur dengan Altman's ZScore berpengaruh negatif terhadap opini audit going concern. Bukti lain menegaskan bahwa variabel prior opinion yang diukur dengan variabel dummy mengurangi hubungan antara prediksi kebangkrutan dan opini audit going concern.
\end{abstract}

Kata Kunci: Prediksi Kepailitan, Ukuran Perusahaan, Opini Audit Going Concern, Pendapat Sebelumnya, Tahun Boneka. 


\section{PENDAHULUAN}

Tujuan penelitian ini untuk menguji pengaruh prediksi.kebangkrutan terhadap opini audit going concern. Selain itu, penggunaan variabel moderating prior opinion sebagai variabel moderating. Salah satu Hasil pemeriksaan Auditor independen yaitu memberikan Opini audit going concern. Opini ini ialah opini audit yang diberikan oleh auditor independen jika dalam laporan keuangannya disimpulkan belum sesuai dengan Standar Akuntansi Keuangan. Selain itu, terdapat masalah keuangan di perusahaan tersebut akan tetapi masih bisa beroperasi usahanya. (Maffei et al., 2020). Standar Profesional Akuntan Publik (SPAP) 2011 opini audit going concern yaitu opini audit yang diberikan auditor indepeden dengan modifikasi serta terdapat ketidakmampuan.atau ketidakpastian keberlangsungan perusahaan.

Opini audit going concern dapat menjadi early warning bagi pihak manajemen untuk mengambil keputusan yang tepat sehingga dapat menekan resiko dan menghindari kemungkinan kebangkrutan. Opini audit going concern juga bermanfaat bagi pihak investor maupun kreditor untuk sebuah referensi sebelum melakukan investasi. Dengan demikian pentingnya opini audit going concern agar keputusan atau kebijakan yang yang diambil menjadi tepat sesuai harapan pemilik dan stakeholders (Kozjak, 2020).

Berdasarkan Peraturan Bursa Efek Indonesia No. I-1 mengenai Penghapusan Pencatatan dan Pencatatan ulang Saham di BEI, bursa akan melakukan penghapusan pencatatan tercatat berdasarkan ketetapan peraturan ini jika perusahaan tercatat mengalami situasi atau peristiwa yang secara signifikansi berdampak negative pada keberlangsungan usaha perusahaan tercatat, baik secara finansial, hukum atau pada keberlangsungan keadaan perusahaan tercatat tidak bisa menyatakan tanda-tanda pemulihan yang cukup.

Periode tahun 2014-2019, Bursa Efek Indonesia (BEI) telah mengeluarkan 12 (dua belas) emiten dari bursa, 5 (lima) diantaranya disebabkan tidak mampu mempertahankan kelangsungan usaha karena mengalami kerugian (Sumber: www.idx.co.id, 2019). Hal ini menunjukan menurunnya kesehatan keuangan menyebabkan keraguan kemampuan perusahaan untuk going concern. Sementara itu menurut Poulus (Cenciarelli et al., 2018) berpendapat bahwa semakin menurun kesehatan keuangan perusahaan dalam hal ini akan semakin tinggi auditor independen dalam memberi opini going concern. Penyebabnya karena prediksi kebangkrutan sebagai salah satu cara mendeteksi kesehatan keuangan perusahaan, sehingga dapat membantu auditor independen memberikan opini going concern untuk kewajaran laporan keuangannya.

Penelitian (Salawu et al., 2017) membuktikan prediksi kebangkrutan berdampak pada penurunan opini audit going concern. Akan tetapi pembuktian berbeda dilakukan oleh Kurnia dan Cellica (2016) yaitu prediksi.kebangkrutan tidak dapat menurunkan opini audit going concern. Sejumlah studi sebelumnya mengahsilkan pembuktian yang berbeda sehingga tidak dapat disimpulkan. Hal ini diduga ada variabel lain yang dapat berpengaruh hubungan prediksi kebrangkutan terhadap opini audit going concern. Variabel tersebut yaitu prior opinion sebagai variabel moderasi.

Penggunaan variabel prior opinion sebagai variabel moderasi didasarkan pada konsep (Krishnan dan Wang, 2015) berpendapat bahwa pendapat opini audit going concern yang diberikan auditor independen dengan mempertimbangkan opini auditor sebelumnya atau 
prior opinion. Selanjutnya menurut (Mutchler, 1984) bahwasanhya apabila perusahaan diberikan opini audit going concern dalam periode sebelumnya (prior opinion), dalam ini memungkinkan akan memperoleh opini yang sama untuk periode laporan keuangan yang diperiksanya. Hal itu disebabkan kualitas laporan keuangan periode yang sebelumnya tidak berbeda dengan periode laporan keuangan tahun berjalan serta perusahaan belum menunjukkan upaya untuk perbaikan terhadap kondisi keuangan perusahaan (Achyarsyah, 2016). Penelitian (Zięba et al., 2016) yang menyatakan bahwasanya prior opinion berdampak signifikansi positif pada opini audit going concern.

Berdasarkan hasil studi sebelumnya yaitu prior opinion dipergunakan oleh auditor independen dalam mempertimbangkan opini terkait going concern perusahaan. Sehingga peneliti termotivasi untuk melakukan pembuktian bahwa prior opinion dapat menurunkan hubungan antara prediksi kebangkrutan pada opini audit going concern.

\section{KAJIAN TEORI}

Teori Sinyal (signaling theory). Studi ini melalui penggunaan teori sinyal untuk mendeskripsikan pertanyaan penelitian. Teori sinyal ialah strategi bagi perusahaan untuk menyampaikan sinyal terhadap stakeholder, yakni berbentuk informasi yang dituangkan oleh manajemen melalui laporan keuangan (Connelly et al., 2011). Informasi ialah hal penting bagi stakeholder, Hal ini dikarenakan berisi informasi tentang pengeleloaam perusahaan periode yang lalu dan masa mendatang terhadap keberlangsungan hidup sebuah perusahaan. Stakeholder membutuhkan informasi guna mengontrol dana yang telah di investasikan dan juga untuk pengambila keputusan yang benar dalam berinvestasi. Oleh karenanya, stakeholder dapat memperoleh informasi tersebut dengan menganalisis prediksi kebangkrutan yang terdapat dalam laporan keuangan perusahaan. Dikarenakan prediksi kebangkrutan dapat mencerminkan kesehataan keuangan suatu perusahaan. Asimetri informasi ialah inti dari masalah teori sinyal. Asimetri informasi merupakan ketidaksetaraan informasi antar manajer dan stakeholder, karena manajer yang mengatur perusahaan memiliki sejumlah informasi tentang perusahaan daripada stakeholder. (Spence, 2002) menunjukkan bahwasanya teori sinyal secara mendasar bisa mengurangi asimetri informasi antar kedua pihak.

Opini.Audit Going Concern. Menurut Standar Operasi Akuntan Publik (SPAP) 2011, opini audit going concern ialah opini audit yang di modifikasi yang sedang penilaian auditor, kelangsungan hidup perusahaan memiliki kekurangan atau ketidakpastian yang besar.

Menurut (Blay et al., 2016) berpendapat going concern dibagi menjadi dua, pertama yaitu keuangan terdiri dari kekurangan (defisiensi) likuiditas, defisiensi, Penangguhan pembayaran Utang serta sulitnya mendapatkan dana. Kedua yakni terjadi kerugian secara berkesinambungan, pendapatan yang diragukan terealisasi, keberlanjutan usaha terhambat dan internal kontrol yang kurang optimal.

Melalui opini audit going concern, auditor mengaggap bahwasanya perusahaan itu sendiri diragukan dalam mempertahankan keberlangsungan hidupnya sehingga memungkinkan terjadinya kebangkrutan. Hal ini selaras dengan (Zaher, 2015) yang 
mengungkapkan bahwa keputusan going concern dapat memprediksi kemungkinan suatu perusahaan mengalami kebangkrutan atau tidak. Standar Profesional Akuntan Publik SA Seksi 341 menjelaskan pada dasarnya terdapat hal yang bisa memberi pengaruh auditor dalam menerbitkan opini audit going concern yaitu: a) Tren negatif; b) Kemungkinan adanya financial distress, c) Masalah intern Perusahaan, d) Masalah ekstern. Oleh karena itu, prediksi kebangkrutan dibutuhkan sebagai alat dalam mendeteksi kesehatan keuangan perusahaan, sehingga dapat membantu auditor dalam memberi opini yang tepat atas going concern sebuah perusahaan.

Prediksi Kebangkrutan. Kebangkrutan ialah ketidakmampuan perusahaan menyelesaikan utangnya saat jatuh tempo sehingga terjadinya kerugian dan menyebabkan kesulitan likuiditas. (Blanco et al., 2015).Kegagalan keuangan disebabkan tingkat return yang diperoleh perusahaan lebih kecil dibanding pada biaya yang ditanggungnya. Hal ini menyebabkan terakumulasi kesulitan keuangan dalam jangka panjang sehingga mengakibatkan nilai aset yang lebih kecil dibanding hutangnya (Kingyens et al., 2016).

Menurut (McKeown, 1991) Tidak optimalnya pendapatan perusahaaan akan menyebabkan kondisi keuangan mengalami ketidakstabilan sehingga akan mendapatan opini dari auditor independen yaitu opini audit going concern. Akan tetapi, perusahaan yang stabil kondisi keuangannya memungkinkan auditor akan memberikan opini selain audit going concern. Selanjutnya, Prediksi kebangkrutan bertujuan memberikan informasi bagi pihak internal maupun stakeholder untuk penilaian kinerja. Informasi tentang prediksi kebangkrutan diperoleh diawal maka kebnagkrutan akan segera diketahui sehingga dilakukan suatu evaluasi ata kebijakan manajemen serta memnyusun strategi untuk perbaikannya Menurut (Mavengere, 2015) informasi prediksi kebangkrutan dapat digunakan oleh investor, pemerintah, akuntan dan manajemen. (Altman dan McGough, 1974) berpendapat model prediksi kebangkrutan meberikan informasi kepada auditor independen untuk menilai keberlangsungan usaha serta sebagai informasi awal untuk mendeteksi yang sulit diperoleh saat dilakukan pemeriksaaan.

Sebuah studi mengenai prediksi kebangkrutan ialah Multiple Discriminant Analysis yang dilaksanakan oleh Altman yaitu analisis Z-Score. Altman Z-Score mempunyai tingkat keakurasi $95 \%$ di industri.manufaktur yang terdaftar di pasar modal.Amerika Serikat. Selanjtnya, Altman menyempurnakan model Z-Score dengan cara menggunakan sejumlah sampel melalui iklim ekonomi yang berbeda-beda yang memberikan hasil prediksi kebangkrutan sebesar 82\% sampai 85\%. Altman Z-Score dapat dijadikan alat untuk memprediksi potensi kebangkrutan dengan menganalisa laporan keuangan perusahaan 2 sampai 5 tahun sebelum perusahaan mengalami kerugian. Z-Score merupakan penilaian ditetapkan dari hitungan standar kali nisbah keuangan yang menghasilkan tingkat kebangkrutan perusahaan. Hasil penilaian tersebut digunakan memprediksi kebangkrutan. Formula Altman ialah suatu multivarate formula yang dipergunakan untuk melakukan pengukuran kondisi keuangan perusahaan. Dengan demikian audtor independen bila menggunakan formula Altaman secara early warning system mendapatkan informasi kondisi pengelolaan perusahaan secara menyeluruh. 
Prior Opinion. Menurut (Mutchler, 1984) berpendapat jika perusahaan yang memperoleh opini audit going concern di tahun sebelumnya maka akan memperoleh opini yang sama di tahun berjalan cenderung terhadap penerimaan opini yang sama ditahun berjalan. Kondisi ini karena pengelolaan perusahaan sama seperti kondisi periode sebelumnya (Dewi et.al, 2016).

Penelitian (Mutchler, 1985) membuktikan bahwa dampak adanya informasi publik pada perediksi opini audit going concern, yakni jenis opini audit yang diterimanya oleh perusahaan. Terdapapat kesimpulan pada studi ini bahwasanya model discriminant analysis yang memesukkan jenis opini audit ditahun sebelumnya memiliki tingkat akurasi prediksi secara menyeluruh tertinggi yakni $89,9 \%$ daripada model yang lainnya.

Prediksi Kebangkrutan dan Opini Audit Going Concern. Dalam kaitannya dengan opini audit going concern, perusahaan dengan laporan keuangan yang memperoleh opini audit going concern dianggap sebagai sinyal oleh receiver. Hal ini disebabkan, perusahaan itu sendiri diragukan keberlangsungan usahanya oleh pihak yang independen, yaitu auditor. Maka feedback yang akan diberikan oleh receiver kepada signaler ialah feedback negatif, di mana para pemegang saham dan kreditur akan menarik dananya dari perusahaan, atau calon investor batal menanamkan sahamnya (Yunus et al., 2020). Pendapat tersebut didukung oleh penelitian (Sugiarto dan Fidiana, 2020) dan (Ajisaka, 2020) membuktikan bahwa prediksi kebangkrutan memiliki pengaruh negatif pada pemberian opini audit going concern. Dengan demikian bahwasanya model prediksi kebangkrutan digunakan untuk membantu auditor independen menilai kondisi keuangan serta pengelolaannya suatu perusahaan, Selain itu, digunakan juga untuk auditor dalam memberi opini audit melalui modifikasi paragraf penjelas going concern. Maka hipotesis penelitian diusulkan di bawah ini:

H1: Prediksi kebangkrutan berpengaruh negatif.terhadap opini audit going concern.

Prediksi Kebangkrutan, Opini Audit Going Concern, dan Prior Opinion. Menurut (McKeown, 1991) Pengelolaan keuangan perusahaan tidak optimal akan menyebabkan keberlangsungan usaha perusahaan. (Host, 2016) berpendapat bahwa Akibat tidak optimalnya pengelolaan perusahaan yang mengakibatkan turunnya pendapat maka keberlangsungan perusahaan semakin menghkahawatirkan yang pada akhirnya akan terus mengalami kerugian. Atas dasar itu auditor independen meragukan keberlangsungan usahanya, maka akan diberikan pendapat dengan paragram penjelas berupa keraguan keberlangsungan usahanya (Mark, 2020). Sementara itu menurut (Thomas et al., 2011) bahwa Auditor independen dalam memberikan pedapat bahwa penadapat auditor independen sebelumnya dijadikan salah satu pertimbangan untuk pemahaman sistem pengendalian intern dan informasi untuk memberikan pendapat auditor padatahun berjalan.

Dengan demikian bukan hanya kondisi keuangan perusahaan saja yang dijadikannya pertimbangan oleh auditor dalam memberikan opini audit going concern, akan tetapi histori perusahaan juga digunakan sebagai bahan pertimbangan. Salah satunya yaitu prior opinion. (Hutagulung dan Triyanto, 2021) serta (Syarif et al., 2021) membuktikan bahwa prior opinion memiliki pengaruh positif pada opini audit going concern. Maka hipotesis peneltian 
ini dirumuskan sebagai berikut.

H2: Pengaruh prediksi kebangkrutan terhadap opini audit going concern dimoderasi oleh prior opinion.

\section{METODELOGI}

Tujuan penelitian untuk membuktikan pengaruh prediksi kebangkrutan pada audit opinion going concern dengan prior opinion sebagai variabel moderasi di Industri manufaktur yang tercatat di Bursa Efek Indonesia periode 2014-2019. Data yang digunakan pada studi ini ialah data sekunder berupa laporan keuangan dan laporan tahunan periode 2014 - 2019. Sample yang digunakan yaitu industri manufaktur yang terdaftar di Bursa Efek Indonesia yang mendapatkan opini laporan keuangan dari akuntan publik yaitu audit opinion going concern. Pengambilan periode penelitian tahun 2014-2019 dikarenakan pada periode tersebut dari beberapa jenis industri yang tercatat di Bursa Efek Indonesia, jenis industri manufaktur yang paling banyak didelisting dari BEI (idx.co.id, 2019). Data yang digunakan yaitu Periode pengamatan tahun 2014-2019 sebesar 140 sampel yang tercatat di Bursa Efek Indoensia, berdasarkan metode purposive sampling maka didapatkan jumlah data observasi sebesar 208 data.

Variabel dan Pengukuran. Studi ini memberi opini audit going going concern concern yang diukur dengan variabel dummy. Opini audit going concern (GC) diberi kode 1, dan opini audit non going concern (NGC) di beri kode 0. Pengukurannya merujuk pada penelitian (Nurkhasanah dan Nurbaiti, 2020). Pengukuran prediksi kebangkrutan merujuk pada penelitian (Saputra, 2019) dengan menggunakan persamaan $Z=1,2 X_{1}+1,4 X_{2}+.3,3 X_{3}$ $+0,6 X_{4}+1 X 5$. Selanjutnya, variabel prior opinion apabila perusahaan memiliki opini GC ditahun sebelumnya, maka akan memberikan angka 1, jika opini NGC memberikannya angka 0 dengan merujuk pada penelitian (Hadi et al., 2019). Penelitian ini menggunakan firm size sebagai variabel kontrol. Firm size (ukuran perusahaan) ialah skala yang bisa membagi suatu perusahaan dijadika sebuah perusahaan besar, menengah dan kecil (Saifudin, 2016). Di sisi lain studi ini mempergunakan dummy tahun sebagai variabel kontrol. Nilai 1 diberi di tahun j, dan (0) nol ditahun lainnya. Penggunaan dummy tahun ini mengacu terhadap studi (Setiany, 2016). Dummy tahun dipergunakan dalam mengontrol perubahan lingkungan makroekonomi dalam periode penelitian (Qi et al., 2000).

Analisis Data. Studi ini mempergunakan Analisis data statistik deskriptif serta dilakukan pengujian hipotesis yaitu analisis regresi. Pengujian statistik deskriptif memberikan informasi data dengan hasil nilai rata-rata, standar deviasi, varians, maksimal, dan minimal dalam tiap data observasi yang digunakan (Ghozali, 2001). Tujuan uji ini yaitu memberi informasi gambaran umum mengenai pendistribusian dan perilaku data sampel.

Kemudian diuji melalui analisis regresi, yang memiliki tujuan ddalam melakukan uji memprediksi model dan menguji hipotesis penelitian. Persamaan regresi berganda yang dipergunakan dalam menguji hipotesis pada studi ini ialah: 
$\mathrm{OAGC}=\beta_{0}+\beta_{1} \mathrm{PK}+\beta_{2} \mathrm{FM}+\beta_{3} \mathrm{DT}$

$\mathrm{OAGC}=\beta_{0}+\beta_{1} \mathrm{PK} * \mathrm{PO}+\beta_{2} \mathrm{FM}+\beta_{3} \mathrm{DT}$

Dimana:

OAGC = Opini Audit.Going Concern

$\beta_{0} \quad=$ Konstanta

PK $\quad=$ Koefisien regresi untuk Prediksi Kebangkrutan

$\mathrm{PK} * \mathrm{PO}=$ Koefisien regresi untuk interaksi

FM = Koefisien regresi untuk Firm Size

DT $\quad=$ Koefisien regresi untuk Dummy Tahun

\section{HASIL DAN PEMBAHASAN}

Deskriptif Data. Populasi pada studi ini ialah Industri Manufaktur sub sektor industri dasar dan kimia yang tercatat di BEI dalam periode 2014-2019 yang berjumlah 140 sampel. Teknik pengambilan sample ynag digunakan yaitu purposive sampling, sehingga jumlah sampel yang didapatkan ialah 208 data observasi. Di bawah ini ialah hasilnya:

Tabel 1. Sampel Penelitian

\begin{tabular}{|c|c|c|}
\hline No & Keterangan & Jumlah Perusahaan \\
\hline 1 & $\begin{array}{l}\text { Industri manufaktur subsektor industri.dasar dan kimia } \\
\text { tercatat di Bursa Efek Indonesia dalam periode 2014- } \\
2019\end{array}$ & 140 \\
\hline 2 & $\begin{array}{l}\text { Industri manufaktur subsektor industri dasar dan kimia } \\
\text { yang tidak tercatat secara terus-menerus dalam peri }\end{array}$ & -33 \\
\hline & ode 2014-2019 & \\
\hline 3 & $\begin{array}{l}\text { Industri manufaktur subsektor industri dasar dan kimia } \\
\text { yang menggunakan mata uang dollar selama periode } \\
\text { 2014-2019. }\end{array}$ & -24 \\
\hline 4 & $\begin{array}{l}\text { Industri manufaktur subsektor industri dasar dan kimia } \\
\text { yang tidak memiliki informasi lengkap pada annual } \\
\text { report nya. }\end{array}$ & -31 \\
\hline \multirow[t]{3}{*}{5} & Jumlah perusahaan sampel & 52 \\
\hline & Tahun pengamatan & 4 \\
\hline & Jumlah Data observasi total selama periode penelitian & 208 \\
\hline
\end{tabular}

Bagian ini menyajikan analisis statistik deskriptif 208 laporan tahunan dari sampel perusahaan industri manufaktur yang tercatat di BEI dalam periode tahun 2014 hingga 2019 dan variabel yang dipergunakan dalam studi ini. 
Table 2. Deskriptif Statistik

\begin{tabular}{lccccc}
\hline & N & Min & Max & Mean & $\begin{array}{c}\text { Std. } \\
\text { Deviation }\end{array}$ \\
\hline PK & 208 & $-1,72$ & 12,47 & 3,53 & 2,18 \\
GC & 208 & 0,00 & 1,00 & 0,13 & 0,33 \\
PO & 208 & 0,00 & 1,00 & 0,13 & 0,33 \\
Valid N & 208 & & & & \\
(listwise) & & & & & \\
\hline
\end{tabular}

\section{Keterangan:}

PK: Prediksi Kebangkrutan

GC: Opini Audit Going Concern

PO: Prior Opinion

Statistik deskriptif dalam tabel 2 dapat diketahui bahwa hasil analisa melalui penggunaan statistik deskriptif pada variabel prediksi kebagkrutan (PK) pada statistik deskriptif menunjukan nilai minimal yakni $-1,72$, nilai maksimal yakni 12,47 , melalui mean 3,53 dan nilai standar deviasi yaitu 2,18 melalui jumlah sampel yang di teliti yaitu 208 perusahaan. Nilai mean Z-Score ialah 3,53 berada pada cut-off $Z>2,99$ artinya rata-rata dari perusahaan yang dijadikan sampel memiliki tingkat keuangan yang sehat.

Hasil analisis dengan penggunaan statistik deskriptif pada variabel opini audit going concern (GC) dari 208 data observasi yang dijadikan sampel memiliki nilai minimal yaitu 0 sampa, nilai maksimal ialah 1 , melalui nilai mean yakni 0,13 dan nilai standar deviasi 0,33 . Nilai 0,13 lebih kecil dari 0,5 hasil tersebut membuktikan bahwasanya lebih sedikit industri manufaktur yang memperoleh opini going concern dari seluruh sampel perusahaan yang ditelitinya. Ada 27 perusahaan yang memperoleh opini audit going concern dalam 208 perusahaan, dan 181 perusahaan menerima opini audit non going concern.

Hasil analisis melalui penggunaan statistik deskriptif pada variabel opini audit prior opinion (PO) dari 208 perusahaan manufaktur yang dijadikan sampel mempunyai skor minimal 0 , skor maksimal yakni 1 , melalui nilai mean yakni 0,13 dan nilai standar deviasi 0,33 . Nilai 0,13 lebih kecil dari 0,5 , hasil itu sendiri menunjukan bahwasanya lebih kecil perusahaan manufaktur yang menerima opini audit going concern pada tahun sebelumnya dari keseluruhan sampel perusahaan yang diteliti. Terdapat 26 perusahaan yang menerima opini audit going concern dari 208 perusahaan dan terdapat 182 perusahaan yang mendapatkan opini audit non going concern pada tahun sebelumnya. 
Hasil Pengujian Hipotesis. Hasil uji hipotesis pada studi ini dilakasanakan melaui penggunaan analisis regresi berganda serta moderate regression analysis (MRA). Hasil pengujian regresi.berganda setelah menunjuka hasil pada Tabel 3.

Tabel 3. Hasil Analisis.Regresi

\begin{tabular}{|c|c|c|c|}
\hline Variabel & Koefisien & $\mathbf{T}$ & p-value \\
\hline (Constant) & 11,224 & 6,150 & 0,000 \\
\hline PK & $-0,011$ & $-0,231$ & $0,012^{*}$ \\
\hline $\mathrm{PO}$ & 0,060 & 0,077 & 0,812 \\
\hline $\mathrm{PK} * \mathrm{PO}$ & $-0,007$ & $-0,325$ & $0,037^{*}$ \\
\hline FS & 0,012 & 1,452 & $0,000^{*}$ \\
\hline DT_2015 & 0,023 & 0,140 & $0,001^{*}$ \\
\hline DT_2016 & $-2,090$ & $-2,540$ & $0,000^{*}$ \\
\hline DT_2017 & 0,020 & 1,459 & $0,002^{*}$ \\
\hline DT_2018 & 0,040 & 0,332 & 0,293 \\
\hline DT_2019 & 0,210 & 1,334 & 0,119 \\
\hline$R$ Square & 0,223 & & \\
\hline Adjusted.R Square & 0,312 & & \\
\hline $\mathrm{F}$ & 4,479 & & \\
\hline Sig & 0,000 & & \\
\hline
\end{tabular}

(*) signifikan pada tingkat $5 \%$

\section{Keterangan:}

PK: Prediksi Kebangkrutan

GC: Opini Audit Going Concern

PO: Prior Opinion

FS: Firm Size

Tabel 3 menunjukkan hasil regresi antar variabel bebas dan variabel terikat. Variabel prediksi kebangkrutan (PK) mempunyai nilai koefisiensi negatif -0,011 melalui taraf Sig. yakni 0,012 ( $p$-value < 0,05). Maka hal ini bisa diartikan bahwasanya prediksi kebangkrutan memiliki pengaruh negatif pada opini pengauditan going concern. Hasil ini membuktikan bahwasanya prediksi kebangkrutan memiliki pengaruh negatif pada opini pengauditan going concern. Dalam ini Hipotesis 1diterima. Studi ini senada pada studi Zaher (2015) dan Salawu et al., (2017) menyatakan bahwasanya prediksi kebangkrutan memiliki pengaruh negative pada opini pengauditan going concern. 


\section{DISKUSI}

Sejalan dengan PSA No. 29 paragraf 11 huruf d yang menyatakan bahwa, keraguan kemampuan satuan usaha dalam mempertahankan kelangsungan hidupnya (going concern) merupakan keadaan yng mengharuskan auditor menambahkan paragraf penjelasan (atau bahasa penjelasan lain) dalam laporan audit. Maka ini dapat dinyatakan bahwasanya semakin baik keadaan keuangan perusahaan, maka akan kecil kemungkinan bagi auditor untuk memberi opini pengauditan going concern. Begitupun sebaliknya, jika situasi keuangan perusahaan memburuk, maka akan besar kemungkinan perusahaan memperoleh opini pengauditan going concern. Pembuktian ini dengan asumsi teori yang digunakan yaitu teori sinyal. Teori sinyal mengatakan bagaimana perusahaan memberi sinyal terhadap stakeholder, yakni berbentuk informasi yang dituangkan oleh manajemen melalui laporan keuangan. Informasi tersebut merupakan sinyal yang dikirim dari pihak manajer perusahaan kepada stakeholder. Stakeholders yang menerima sinyal akan menginterpretasikan sinyal tersebut. Kemudian stakeholders akan memberikan feed back kepada perusahaan. Semakin buruk kondisi perusahaan maka akan semakin memburuk pula sinyal yang akan diterimanya oleh stakeholder dan perusahaan cenderung mendapatkan opini pengauditan going concern, artinya kelangsungan hidup perusahaan diragukan oleh pihak yang independen.

Hasil pengujian Interaksi antara variabel Prediksi Kebangkrutan (PK) dengan Prior Opinion (PO) menghasilkan nilai signifikan sebesar 0,037 ( $p$-value $<0,05$ ) dengan nilai koefisien -0,07 menunjukan bahwa Variabel prior opinion dapat menurunkan dampak Prediksi Kebangkrutan pada Audit opnion Going Concern. Maka bisa disimpulkan bahwa variabel prior opinion memoderasi dengan memperkuat hubungan variabel prediksi kebangkrutan terhadap opini pengauditan going concern. Dengan demikian Hipotesis 2 berhasil diterima. Hal ini menunjukkan bahwasanya opini yang diterima oleh perusahaan di tahun sebelumnya, mempengaruhi pemberian opini audit going concern oleh auditor terhadap perusahaan yang mempunyai nilai Z-score yang rendah. Apabila auditor pada tahun sebelumnya memberikan opini audit going concern kepada perusahaan, ini memberikan sinyal bahwa perusahaan memiliki masalah dengan kelangsungan hidup perusahaan sehingga akan semakin besar kemungkinan perusahaan akan mendapat opini audit going concern pada tahun berjalan (Wibisono, 2013). Sehingga, hal ini akan mempengaruhi kepercayaan stakeholder kepada perusahaan dan akan mengakibatkan perusahaan tersebut lebih cepat mengalami kebangkrutan karena banyak stakeholder dan investor yang enggan berinvestasi dan membatalkan investasinya (Kurniati, 2012). Sebaliknya, jika auditor memberikan opini audit non going concern pada perusahaan di tahun sebelumnya maka hal ini memberikan sinyal bahwa perusaahan memiliki kinerja keuangan yang baik dan tidak mengalami kebangkrutan sehingga, perusahaan akan mendapat opini audit yang sama dengan opini audit sebelumnya. Maka, dapat disimpulkan bahwa prior opinion dapat memperkuat hubungan prediksi kebangkrutan terhadap audit going concern.

Selain permasalahan keuangan, prior opinion juga merupakan sebuah faktor yang memberi pengaruh akan penerimaan opini pengauditan going concern (Dewi et al., 2016). Sebab, prior opnion yang didapat oleh perusaahan menjadi sinyal bagi pihak eksternal untuk menilai keadaan perusaahan dimasa sekarang dan dapat meramalkan keadaan perusahaan 
dimasa yang akan datang (Dewi dan Premashanti, 2020). Maka, keberadaan prior opinion menjadi penting karena dijadikan sebagai bahan pertimbangan auditor untuk mengeluarkan opini pada tahun berjalan. Perusahaan yang mendapatkan opini going concern di tahun sebelumnya cenderung memperoleh opini yang sama pada tahun berjalan (Mutchler, 1984). Hal ini dikarenakan keadaan perusahaan pada tahun sebelumnya tidak jauh berbeda pada tahun berjalan. Selain itu, adanya hipotesis self-fulfilling properchy yang menunjukkan bahwasanya apabila auditor memberi opini going concern terhadap perusahaan, maka kemungkinan besar perusahaan tersebut lebih cepat mengalami kebangkrutan, sebab investor atau kreditur cenderung menghindari investasi dengan perusahaan yang diragukan dalam kelangsungan hidupnya, sehingga mereka memilih melakukan pembatalan berinvestasi atau mengambil dananya dari perusahaan itu sendiri (Dewi et al, 2016). Selain itu, perusahaan yang sebelumnya mendapatkan prio opinion going concern akan memiliki kecenderungan mengalami permasalahan- permasalahan baru di tahun berjalan yang akan mengancam kelangsungan hidup perusahaan (Pratiwi dan Lim, 2018).

Oleh karena itu, opini audit going concern yang didapat perusahaan merupakan dilakukan early warning bagi perusahaan sehingga dapat membantu perusahaan dalam mengambil strategic action untuk mengurangi permasalahan (Kusumayanti, 2017). Setelah mendapatkan prior opinion going concern perusahaan dituntut untuk melakukan perbaikan terhadap kinerja keuangan perusahaan, namun dalam kurun waktu satu tahun sebelum dilakukan audit selanjutnya tidak cukup untuk melakukan perbaikan- perbaikan kinerja keuangan (Septiana dan Khatimah, 2021). Sehingga, apabila suatu perusahaan melalui opini audit going concern tidak memperbaiki kinerja keuangan maka perusahaan tersebut cenderung menerima kembali opini pengauditan going concern. Hasil studi ini senada pada studi sebelumnya oleh (Maffei, 2020); (Kurnia dan Cellica, 2016) yang menemukan hasil bahwasanya prior opinion berdampak positif pada opini audit going concern.

Hasil uji variabel kontrol firm size (FS) mempunyai koefisiensi positif sebanyak 0,012 melalui taraf Sig. 0,00 ( $p$-value < 0,05). Maka bisa diartikan bahwasanya firm size memiliki pengaruh positif pada opini audit going concern. Studi ini sejalan pada studi oleh (Pham, 2017) dan (Xu et al., 2018) yang menunjukan bahwasanya firm size memiliki pengaruh positif pada opini audit going concern. Dalam ini menyatakan bahwasanya besarnya asset yang dimiliki suatu perusahaan, maka akan besar pula peluang bagi perusahaan dalam penerimaan opini audit going concern. Studi ini juga sejalan dengan penelitian yang dilakukan oleh (Minerva et al., 2020) yang menyimpulkan bahwa perusahaan baik berskala besar maupun kecil sama-sama memiliki peluang yang sama dalam menghadapi masalah kebangkrutan, sehingga baik perusahaan besar maupun kecil jika berindikasi mengalami masalah kebangkrutan tetap akan menerima opini audit going concern. Menurut (Diyanti, 2012) semakin besar ukuran perusahaan maka semakin terjamin kelangsungan hidup perusahaan tersebut di masa yang akan datang, oleh karena itu besar kecilnya ukuran perusahaan berpengaruh terhadap penerimaan opini audit going concern. 


\section{KESIMPULAN}

Hasil studi ini bertentangan dengan studi yang dilakukan oleh (Azizah dan Anisykurlillah, 2014) yang menyatakan ukuran perusahaan tidak berpengaruh terhadap penerimaan opini audit going concren, karena perusahaan besar akan dengan mudah menangani kondisi keuangan yang buruk karena perusahaan besar memiliki SDM yang lebih baik dan auditor dalam memberikan opini audit going concern cenderung melihat kondisi keuangan perusahaan dibandingkan dengan ukuran perusahaan. (Azizah dan Anisykurlillah, 2014) menyatakan perusahaan besar dapat mengalami financial distress, hal ini terjadi karena pertumbuhan asset perusahaan tidak diikuti dengan kemampuan entitas untuk meningkatkan saldo labanya atau dengan kata lain meskipun perusahaan memiliki total asset yang besar, namun perusahaan mengalami rugi operasi secara terus-menerus sehingga terjadi financial distress.

Variabel kontrol lainnya yaitu dummy tahun (DT) 2014 sampai dengan 2019 membuktikan bahwa memiliki koefisien negatif yaitu DT_2016 yakni -2,090 melalui nilai signikansi 0,000, Hal ini membuktikan bahwa Variabel kontrol dummy tahun 2016 berpengaruh menurunkan opini audit going concern. Sedangkan dummy tahun lainnya yaitu DT_2015; DT_2017 nilai koefisien yakni 0,023 dan 0,020 melalui nilai siginifikansi yaitu 0,001 dan 0,002. Hasil ini mnyimpulkan bahwa DT_2015 dan DT_2017 berpengaruh meningkatkan opini audit going concern. Hasil ini sejalan dengan kondisi ekonomi Indonesia pada industri manufaktur yang memiliki pertumbuhan yang baik. Pertumbuhan PDB manufaktur pada periode 2015 sampai 2017 masing-masing sebesar 4,33\%, 4,26\%, dan 4,29\%. Laju pertumbuhan ini menunjukkan trend positif.

Sementara itu hasil pembuktian DT_18 dan DT_19 menyimpulkan hasil nilai signifikasni yakni 0,293 dan 0,119 melalui nilai koefesien yakni 0,040 dan 0,210. Hasil ini membuktikan bahwa DT_18 dan DT_19 tidak berpengaruh terhadap opini audit going concern. Adapun hasil pengamatan pada tahun 2018 yang tidak berpengaruh terhadap opini audit going concern disebabkan karena pertumbuhan ekonomi pada industri manufaktur yang mengalami penurunan. Berdasarkan data Badan Pusat Statistik (BPS) pertumbuhan ekonomi industri manufaktur pada kuartal II tahun 2018 sebesar 3,54\% secara tahunan (year-on-year/YoY). Angka pertumbuhan tersebut melambat dari tahun sebelumnya yaitu sebesar 3,88\%. Hasil pengamatan pada tahun 2019 menunjukkan bahwa tidak terdapat pengaruh terhadap opini audiy going concern. Karena dalam perkembanganya, porsi industri manufaktur juga berada dalam trend penurunan, porsi tersebut menunjukkan angka sebesar 19,52\% pada kuartal II pada tahun 2019.

\section{DAFTAR PUSTAKA}

Achyarsyah, P. (2016). The Analysis of The Influence of Financial Distress, Debt Default, Company Size, and Leverage on Going Concern Opinion. Repository.Unas.Ac.Id, 14(10), 6767-6783. http://repository.unas.ac.id/id/eprint/62.

Ajisaka, M. (2020). Pengaruh Profitabilitas, Financial Distress, Dan Pertumbuhan Perusahaan Terhadap Opini Audit Going Concern. Opinion Logit Model. Managerial Auditing Journal, 19(1), 183-199. https://doi.org/10.1108/ARJ-06-2013-0033. 
Alaminos, D., Castillo, A. D., and Fernández, M. Á. (2020). Going Concern Opinion Prediction For Football Clubs: Evidence From The Spanish League. Scielo.Org.Mx. http://www.scielo.org.mx/scielo.php?pid=S0186$10422020000100105 \&$ script=sci_arttext\&tlng=en.

Blanco Oliver, A. J., Irimia Diéguez, A. I., Oliver Alfonso, M. D., and Wilson, N. (2015). Improving Bankruptcy Prediction In Micro-Entities By Using Nonlinear Effects And Non-Financial Variables. Finance a Úvěr-Czech Journal of Economics and Finance, 65(2), 81. https://idus.us.es/handle/11441/80856.

Blay, A. D., Bryan, D., \& Reynolds, J. K. (2016). The Going-Concern Market Anomaly Revisited. SSRN Electronic Journal. https://doi.org/10.2139/SSRN.2747774.

Cenciarelli, V. G., Greco, G., and Allegrini, M. (2018). External Audit And Bankruptcy Prediction. Journal of Management and Governance, 22(4), 863-890. https://doi.org/10.1007/s10997-018-9406-z.

Connelly, B. L., Certo, S. T., Ireland, R. D., and Reutzel, C. R. (2011). Signaling Theory: A Review And Assessment. Journal of Management, 37(1), 39-67. https://doi.org/10.1177/0149206310388419.

Dewi, N. N. K., Badera, I. D. N., and Astika, I. B. P. (2016). Prior Opinion Dan Pertumbuhan Perusahaan Sebagai Pemoderasi Pengaruh Model Prediksi Kebangkrutan Altman Pada Pemberian Opini Going Concern. E-Jurnal Ekonomi Dan Bisnis Universitas Udayana, 5(11), 3857-3884.

Guo, Y., Delaney, D., and Ahmed, A. (2020). Is an Auditor's Propensity to Issue Going Concern Opinions a Valid Measure of Audit Quality? Australian Accounting Review, 30(2), 144-153. https://doi.org/10.1111/AUAR.12300.

Hadi, K. K., Gunawan, H., dan Utomo, H. (2015). Pengaruh Likuiditas Solvabilitas Dan Model Predikisi Kebangkrutan (Altman Z-Score) Terhadap Pemberian Opini Going Goncern. Prosiding Akuntansi; Vol 1, No 1, Prosiding Akuntansi (Februari, 2015); 294-303. http://repository.unisba.ac.id:8080/xmlui/handle/123456789/24420.

Hutagalung, S. R., dan Triyanto, D. N. (2021). Pengaruh Kepemilikan Manajerial, Ukuran Perusahaan, dan Kondisi Keuangan Terhadap Opini Audit Going Concern. 8(1), 104111.

Kingyens, A. T., Paradi, J. C., and Tam, F. (2016). Bankruptcy Prediction of Companies in the Retail-Apparel Industry Using Data Envelopment Analysis. International Series in Operations Research and Management Science, 249, 299-329. https://doi.org/10.1007/978-3-319-48461-7_13.

Kozjak, S. K. (2020). Auditor's Going Concern Assessment In The Republic Of Croatia. Economic and Social Development: Book of Proceedings, October, 130-141.

Krishnan, G. V., and Wang, C. (2015). The Relation between Managerial Ability and Audit Fees and Going Concern Opinions. AUDITING: A Journal of Practice \& Theory, 34(3), 139-160. https://doi.org/10.2308/AJPT-50985.

Kurnia, R., and Cellica, L. (2016). The Impact of Bankruptcy Prediction, Company's Financial Condition, Previous Year Audit Opinion, Firm Size and Audit Tenure Towards Auditor's Going Concern Opinion. https://papers.ssrn.com/abstract=3000214.

Maffei, M., Fiondella, C., Zagaria, C., and Zampella, A. (2020). A Multiple Discriminant 
Analysis Of The Auditor's Going Concern Opinion: The Case Of Audit Opinions In Italy. Meditari Accountancy Research, 28(6), 1179-1208. https://doi.org/10.1108/MEDAR-06-2019-0514.

Mavengere, K. (2015). Predicting Corporate Bankruptcy And Earnings Manipulation Using The Altman Z-Score And Beneish M Score. The Case Of Z Manufacturing Firm In Zimbabwe. Author Details: Kudakwashe MAVENGERE- Lupane State University,Department of Accounting and Finance. 10, 8-14.

McKeown, J., Mutchler, J., and W, H. (1991). Toward an Explanation of Auditor Failure to Modify the Audit Reports of Bankrupt Companies. A Journal Of Practice \& Theory, $10,1-13$.

Mutchler, J. (1984). Auditors' Perception of The Going-Concern Opinion Decision. Auditing : A Journal Of Practice and Theory, 17-30.

Nurkhasanah, N. A., dan Nurbaiti, A. (2020). Kondisi Keuangan, Manajemen Laba Dan Profitabilitas Terhadap Penerimaan Opini Audit Going Concern (Studi Empiris Pada Perusahaan Sub Sektor Properti dan Real Estate yang Terdaftar di Bursa Efek Indonesia Tahun 2014-2018). ISEI Accounting Review, 4(1), 1-7. https://doi.org/10.36217/IAR.V4I1.130.

Pham, N. K., Duong, H. N., Quang, T. P., Ho, N., and Thuy, T. (2017). Audit Firm Size, Audit Fee, Audit Reputation and Audit Quality: The Case of Listed Companies in Vietnam. Asian Journal of Finance \& Accounting, 9(1). https://doi.org/10.5296/ajfa.v9i1.10074.

Salawu, R. O., Oladejo, T. M., and Inneh, E. G. (2017). Going Concern And Audit Opinion Of Nigerian Banking Industry. Accounting \& Taxation, 9(1), 63-72.

Saputra, I. (2019). Determinasi Financial dan Non Financial Faktor terhadap Keputusan Opini Audit Modifikasi Going Concern (Prediksi Kebangrutan Perusahaan yang Terdaftar di BEI). Jurnal Akuntansi, 20(1), 15-35.

Spence, M. (2002). Signaling in Retrospect and the Informational Structure of Markets. American Economic Review, 92(3), 434-459. https://doi.org/10.1257/00028280260136200.

Sugiarto, avif R. B. D., dan Fidiana. (2020). Pengaruh Kebangkrutan , Gagal Bayar , Dan Opini Audit Terhadap Penerimaan Opini Audit Going Concern. Jurnal Ilmu Dan Riset Akuntansi.

Syarif, R. M., Saebani, A., dan Julianto, W. (2021). Pengaruh Kualitas Audit, Pertumbuhan Perusahaan dan Kondisi Keuangan Perusahaan Terhadap Penerimaan Opini Going Concern. Jurnal Akuntansi Dan Investasi, 9(2), 197-207. https://journal.umy.ac.id/index.php/ai/article/view/1108.

Xu, H., Dao, M., and Wu, J. (2018). The Effect Of Real Activities Manipulation On Going Concern Audit Opinions For Financially Distressed Companies. Review of Accounting and Finance, 17(4), 514-539. https://doi.org/10.1108/RAF-09-20160135.

Xu, Q., and Kalelkar, R. (2020). Consequences of Going-Concern Opinion Inaccuracy at the Audit Office Level. AUDITING: A Journal of Practice \& Theory, 39(3), 185-208. https://doi.org/10.2308/AJPT-18-050.

Yunus, M., Calen, C., dan Sirait, S. (2020). Pengaruh Prediksi Kebangkrutan Model Altman 
Z-Score, Reputasi Auditor dan Opinion Shopping terhadap Opini Audit Going Concern. Owner, 4(1), 343-355. https://doi.org/10.33395/owner.v4i1.174.

Zaher, A. A. (2015). Going-Concern Opinions, Executive Tenure and Gender. 3(7), 59-78.

Zięba, M., Tomczak, S. K., and Tomczak, J. M. (2016). Ensemble Boosted Trees With Synthetic Features Generation In Application To Bankruptcy Prediction. Expert Systems with Applications, 58, 93-101. https://doi.org/10.1016/J.ESWA.2016.04.001.

Minerva, L., Sumeisey, S. V., Stefani., Wijaya, S., dan Lim, A. C. (2020). Pengaruh Kualitas Audit, Debt Ratio, Ukuran Perusahaan, dan Audit Lag terhadap Opini Audit Going Concern. Riset dan Jurnal Akuntansi. Vol. 4 No. 1.

Diyanti, F. T. (2012). Pengaruh Debt Default, Pergantian Auditor, dan Ukuran Perusahaan terhadap Penerimaan Opini Audit Going Concern.

Anisykurillah, I., dan Azizah, R. (2014). Pengaruh Ukuran Perusahaan, Debt Default, dan Kondisi Keuangan Perusahaan terhadap Penerimaan Opini Audit Going Concern. Accounting Analysis Journal. 